\title{
Bajo tuición. Infancia y extinción en la historia de la colonización fueguina. (Sentidos coloniales II) ${ }^{* *}$
}

Taken into custody. Childhood and Extinction in the history of Tierra del Fuego's colonization

Joaquín Bascopé Julio

\section{(2) OpenEdition}

Journals

\section{Electronic version}

URL: http://journals.openedition.org/corpusarchivos/975

DOI: $10.4000 /$ corpusarchivos. 975

ISSN: 1853-8037

\section{Publisher}

Diego Escolar

Electronic reference

Joaquín Bascopé Julio, «Bajo tuición. Infancia y extinción en la historia de la colonización fueguina

(Sentidos coloniales II) ${ }^{\star \star} »$, Corpus [En línea], Vol 1, No 1 | 2011, Publicado el 30 junio 2011, consultado

el 20 abril 2019. URL : http://journals.openedition.org/corpusarchivos/975 ; DOI : 10.4000/ corpusarchivos.975

This text was automatically generated on 20 April 2019.

Licencia Creative Commons: Atribución-NoComercial 2.5 Argentina (CC BY-NC 2.5 AR) 


\section{Bajo tuición. Infancia y extinción en la historia de la colonización fueguina. (Sentidos coloniales II)}

Taken into custody. Childhood and Extinction in the history of Tierra del Fuego's colonization

Joaquín Bascopé Julio

\section{EDITOR'S NOTE}

Fecha de recepción del original: 04/01/2001

Fecha de aceptación para publicación: 02/05/2011

\section{AUTHOR'S NOTE}

**Para la primera parte de esta tetralogía, ver Bascopé Julio, 2010c.

"En último caso, hágase una campaña de exterminio contra los indios adultos y déjese los niños a cargo de los salesianos". El Magallanes, 11 de marzo de 1894

\section{Presentación}

En 1997 el gobierno australiano publicó el informe Bringing them Home en el que se detalló la política de separación de niños nativos de sus familias iniciada por la Corona Británica y continuada por el Estado australiano, desde fines del siglo XIX y durante más de cien años ${ }^{1}$. El informe recogía testimonios de los sobrevivientes de la stolen generation, cuya 
crudeza sensibilizó a la sociedad australiana y obligó al gobierno a una política de reparaciones y a la presentación de excusas públicas a las víctimas y sus familias. La existencia de una "política indígena" propiamente estatal que organizó la violencia, así como el reconocimiento de "sobrevivientes" a ella, distingue en la forma el caso australiano de la colonización de la Patagonia y, en particular, de la Tierra del Fuego.

Mientras que en Australia el colonizado quedó bajo la tuición de un Protector de Indios, en Tierra del Fuego la debilidad de las instituciones, la ausencia de derecho, libró de hecho la colonización al capital ganadero. Éste, declarando amenazadas sus ovejas por los cazadores fueguinos, gestionó el peligro como un asunto animal. Aquéllos se acabarían por una ley natural: la del avance del capital. De este modo, la figura de la "extinción" - o ausencia de sobrevivientes - se adoptó temprano en la escritura de la historia regional. Al igual que arriesgaron extinguirse en otras explotaciones el lobo marino o la ballena por la pesca, el "Indio" surgió como una especie amenazante para la ganadería y, por tanto, amenazada de extinción.

3 En lo que sigue discutiremos la figura de la extinción mostrando cómo la colonización no acabó al Indio, sino más bien lo originó como objeto - de caza, de civilización y más tarde de ciencia. Aportaremos pruebas sobre el secuestro y adopción forzada de niños fueguinos como una práctica masiva, motivada por la falta de servidumbre, que involucró no sólo a misioneros, sino que se extendió entre funcionarios y empresarios. Sostendremos que la presencia del Indio en el espacio doméstico colonial fue paralela a su inscripción primitiva como infancia de la historia o "prehistoria viviente"2. Presentaremos abundante documentación, hasta ahora inédita o dispersa, que revelará esta conexión y apoyará la hipótesis de que el espacio primitivo asignado a los fueguinos fue un reducto de pureza heredado por la Misión a la Antropología. Una astucia retórica fundada en una práctica concreta de infantilización ${ }^{3}$.

\section{Geopolítica indígena}

Tras el tratado de límites de 1881, los gobiernos chileno y argentino ofrecieron extensas concesiones de tierra, organizadas como estancias, al capital ganadero -al principio de origen británico. Éste se erigió como soberano de facto en Tierra del Fuego. Los grupos nativos que recorrían entonces la isla, divididos según espacios de caza, vieron substituirse los guanacos por las ovejas. Así, el enfrentamiento entre cazadores de humanos y de animales no tardó en estallar, favorecido por la débil o nula mediación estatal.

5 La inexistencia de una "política indígena" en Tierra del Fuego ${ }^{4}$ tuvo una excepción cuando, en 1883, el Vaticano creó la Prefectura Apostólica de la Patagonia. Abarcando el extremo austral chileno y argentino, tuvo su asiento en Punta Arenas y fue encabezada por la orden salesiana, cuyos misioneros asumieron el trabajo de mediación que el Estado, como única decisión, había cedido.

6 Su metodología consistía "en educar y alejar del vi-cio a la juventud pobre y humilde" (Cagliero en Aliaga 1984:12) y pronto se invistieron como defensores del Indio ${ }^{5}$. Con los salesianos, la extinción tendría algunos matices. Si para los exterminadores se trataba simple-mente de bestias, para los misioneros el Indio debía ser un niño, un adolescente o un menor en general, de cuyo pasaje a la adultez serían los tutores: 
7 Los mismos jefes de esta misión nos han dicho que no esperan civilizar a los indios adultos. Lo que ellos persiguen es atraer a las familias [...] para que les confíen sus hijos para educarlos ${ }^{6}$.

8 La creación de dos misiones, una en la Tierra del Fuego argentina (La Candelaria, 1893) y otra en una isla chilena vecina (Dawson, 1889), garantizó el asilo de las cacerías, mientras que el mantenimiento de la tuición dependió del poder de representar al Indio. En ese sentido, el origen italiano y la vocación transnacional de la orden le permitieron situarse como referente de la política patagónica, desmarcándose y hasta desafiando las soberanías chilena y argentina. Representando al Indio, los salesianos establecieron, de hecho, sus propias alianzas con los estancieros.

9 En mayo de 1895 el prefecto apostólico José Fagnano firmó con la principal sociedad ganadera, la Explotadora de Tierra del Fuego (en adelante, SETF), un acuerdo a través del cual ésta prometía deportar a todos los fueguinos que capturase, acompañados de una libra esterlina para su mantenimiento ${ }^{7}$. El entonces gerente de la SETF, Mauricio Braun (cuyo matrimonio había sido bendecido por Fagnano) escribió que en esos días "no pensaba en otra cosa que sacarme a los onas de encima", y en consecuencia multiplicaba esfuerzos para capturarlos y "fletarlos a Dawson". Pero el sello de esta alianza no podía estamparse sin la venia gubernamental. Braun negoció con el representante chileno Manuel Señoret quien, aun-que "opuesto en principio a la explotación ganadera en gran escala, como constituía el millón de hectáreas de la concesión de la Explotadora”, nunca lo defraudó:

10 Mi tesis, que defendí ante él acaloradamente, era que no cabían en la isla la civilización con la barbarie. Si se quería evitar la represión armada contra el robo y la matanza de animales era indispensable eliminar al indio, pero por las buenas y la ocasión la pintaban calva con las misiones salesianas [...] Y aquí también Señoret tuvo que ceder sin convicción porque él y los salesianos no simpatizaban (Braun Ménendez 1985:135).

11 Ante la competencia del poder religioso, que se afirmaría con las deportaciones, Señoret intentó reposicionar a su gobierno ${ }^{8}$. Laico, como muchos de los colonos, pensó una solución civil al "problema del indio" (Braun Menéndez 1985:131) que, sin embargo, nunca tuvo lugar`. Se confirmó, en cambio, que el problema concernía a la gobernación, los misioneros y los estancieros, y su extinción coincidiría con la del Indio.

\section{La necesidad de la infancia}

Fue bajo la forma de un escándalo que, el mismo año de 1895, se tuvo noticia en Santiago del conflicto en Punta Arenas. Apoyando la labor misionera, el diario El Chileno titulaba el 8 de noviembre:

En Magallanes.

Los indios fueguinos y los Salesianos.

Cacerías de indios, escenas de sangre.

Una raza que se extingue.

Al día siguiente continuaba el reportaje:

Grandes escándalos en Magallanes.

Tráfico de indios en Punta Arenas.

El Gobernador Señoret da al pueblo vergonzosos espectáculos.

Repugnantes inmoralidades.

Indios que mueren de abandono y miseria. 
Ambas publicaciones dieron origen a un Sumario sobre vejámenes inferidos a indíjenas de Tierra del Fuego ${ }^{10}(S)$, iniciado un mes más tarde por la joven justicia local ${ }^{11}$. Sucedió que a fines de julio de 1895, el gobernador se enteró de la captura de 165 personas en Tierra del Fuego por empleados de la SETF. Durante un mes se los había mantenido encerrados como ganado en un galpón, esperando, como convenido, la ocasión de de-portarlos. Si creemos a Braun, Señoret "temió que tan considerable grupo pudiera acarrear graves dificulta-des a los padres Salesianos en la Isla Dawson, donde no existe fuerza armada" ( $S$, f. 171). Aunque también pudo ver la oportunidad de aplicar su política indígena. Envió entonces una embarcación de la Armada y desvió a los deportados hacia Punta Arenas ${ }^{12}$, donde fueron hacina-dos en otro galpón, vestidos "por la caridad pública"13 y mantenidos con raciones de carne ${ }^{14}$. Inmediatamente fueron puestos bajo la tuición de una comisión nombra-da por Señoret y encabezada por el estanciero y cónsul alemán y británico, Rodolfo Stubenrauch:

...nos preocupamos en la distribución de los niños mayores de cuatro años y menores de catorce, entre aquellas familias que nos merecían entera confianza y para cuyo efecto hacíamos firmar un contrato a los interesados. Antes de instalar a cualquier niño, pedíamos el consentimiento a sus padres o a los que parecían sus parientes [...] Con respecto a los individuos mayores de catorce años, se les ha dado colocación de diferentes modos (S, ff. 17vta-18).

La rapidez con que desembarcó y se expandió el capital en Punta Arenas no había tenido correlato en la mano de obra disponible - déficit que ayudarían a cubrir los mayores de catorce años- $y$, en particular, de servidumbre doméstica - para lo que se criaría a los menores. Un año antes de la deportación fueguina, ya se sabe que en la ciudad "no existe ni una cuarta parte del número de sirvientas, amas de llaves, cuidadoras de niños, cocineras, etc., que se necesitan"15. Pero si la necesidad de servidumbre sería cubierta por el proyecto civil que Señoret oponía a la Misión, su inconsistencia se reveló rápida-mente, en septiembre de 1895, cuando se deportaron "de Bahía Inútil a Isla Dawson, doce indios [...] por orden de don Moritz Braun"16.

16 En cuanto al consentimiento de los padres o los que pare-cían sus parientes, el cónsul es desmentido, y con él Señoret y los que lo apoyaban ${ }^{17}$, por treinta y dos testigos que durante el Sumario describieron, como en el caso australiano, la separación forzada de las familias. Entre los testimonios destaca el de un policía - la fuerza arma-da ausente en Dawson- que vigiló "la repartición" y vio que "cada persona que deseaba un indio pequeño lo elegía y lo designaba, y el mismo interesado lo quitaba de los brazos de la madre, más veces por la fuerza y otras veces por engaño". Y aunque la policía tenía órdenes de devolver a un hijo "cuando su madre lloraba", igual "de-jaba que se sacara a los niños por la fuerza." ${ }^{18}$ (f. 36) Ante la discrepancia de versiones - del cónsul, de Señoret o de la SETF frente a la "ignominiosa repartición de los indios" (f. 125)-, un vecino admitió que los niños "nunca fueron entregados voluntariamente" pero tampoco "podían serlo porque en esa gente domina el cariño animal de la cría y no el moral” (f. 89vta).

Leída desde el cariño animal, la falta de consentimiento fue en realidad la de los misioneros ante la pérdida de la tuición en favor del gobierno, y fue el escándalo que, a falta de querellante, activó la investigación. Difundido por los salesianos y reproducido en la prensa local y metropolitana, el escándalo consistía en la inversión de los términos coloniales, esto es, que "los pobres indios" tuvieran "la desgracia de verse tratados con crueldad canibalesca por salvajes con trajes de hombres civiliza-dos" ${ }^{19}$. De este modo, los salesianos expusieron su conflicto con Señoret, y el Sumario se jugó en la confirmación o 
refutación del escándalo salvaje. El superior regional Maggiorino Borgatello, principal agitador, reunió a la mayoría de testigos y sus extensas declaraciones no sólo contienen los detalles más crudos, sino que proyectan la falta de consentimiento de los misioneros:

El día 27 de setiembre [de 1895] doña Elvira Ballester pidió al comisario de policía don Alberto Barra ${ }^{20}$ que le diera una indiecita de dos años y medio. Barra mandó un soldado al campamento indígena para quitársela a su madre [...] pero esta se resistió uniéndose todos los indios y con piedras y palos hicieron esfuerzos para rechazar al soldado. Éste viéndose rodeado por tantos indios furiosos sacó un revolver y disparó un tiro que por suerte no hirió a nadie. Los indios espantados dejaron libre al soldado y éste intimó a la mujer india de seguir a la señora Elvira Ballester hasta su casa. Llegada aquí el soldado le quitó el hijo a la india y se lo entregó a la Ballester y dio un empellón a la india. Esta entonces empezó a dar gritos desgarradores, se rasgó con las uñas sus carnes y cayó al suelo casi desmayada. [...] Este hecho pueden atestiguarlo, doña Clorinda Mansilla de Ávila y doña Julia Marechaux. ${ }^{21}$ (S, f. 23vta)

En "La trata de indios en Magallanes", artículo publicado en pleno desarrollo del Sumario, Ramón Serrano (descubridor chileno del interior de Tierra del Fuego y accionista de la SETF) reprodujo el episodio de Ballester, así como la cita de los salvajes con trajes de civilizados, para defender al gobernador. Acusó a los salesianos de la "adulteración de los hechos" y redujo el escándalo a "una farsa" útil a su "guerra" contra Señoret. Para Serrano, la "desazón" de los misioneros se comprendía porque el desvío de los deportados a Punta Arenas interrumpía una "corriente de indígenas y de libras esterlinas de la Tierra del Fuego a la Isla Dawson"22. En fin, con el gobernador y los misioneros disputándose la infancia ante la Ley, fuera de ella quedaron, víctimas y victimarios, irresponsabilizados como las bestias -a las que se puede cazar sin cometer delito- y el soberano -que instituye la ley sin someterse a ella ${ }^{23}$.

Cabe anotar que entre los vecinos que merecían entera confianza para beneficiarse con niños figuraba Mulato, el "apreciable cacique patagón" mostraron, por un lado, la facilidad con que unos podían convertirse en Indio -o niñode otro y, a la vez, la necesidad de un reconocimiento civil, o al menos adulto, para obtener la tuición. En ese sentido, el estatuto infantil de los deportados pareció necesario a la solución del conflicto: el Indio de consenso no podía ser animalizado, como pretendían algunos estancieros, porque los salesianos estarían ahí para denunciarlos, pero tampoco podía incorporárselo como ciudadano pues los misione-ros necesitaban infancia. La vida del Indio amenazado de extinción sólo sería posible en el asilo y bajo la tuición religiosa. Entonces, y como por simetría, la justicia local fue ella misma puesta bajo tuición, la SETF negoció un ministro en visita ${ }^{25} \mathrm{y}$, sin nunca conocer el testimonio ni el nombre de las víctimas -anónimas bajo la cifra de "165"-, el Sumario concluyó sin condenas. Se acordaba, de este modo, una escritura de la extinción que la también joven prensa magallánica ya proponía un año antes de la deportación: “En ultimo caso, hágase una campaña de exterminio contra los indios adultos y déjese los niños a cargo de los salesianos"26.

\section{Hospitalidad salvaje}

21 Más de dos tercios de los deportados fueron estima-dos niños y adolescentes ${ }^{27}$, esto es, distribuibles, aunque sólo 76 figuraban en la Nómina de las personas que tomaron a su cargo Indios Ona publicada el 7 de febrero de 1896 (ver anexo). Al día siguiente quedó a la vista el 
triunfo salesiano y la derrota de Señoret (relevado del cargo al final del año) cuando cuarenta y siete sobrevivientes fueron re-deportados de Punta Arenas a Dawson (todos mayores de 18 años); en abril, ocurrió lo mismo con otros catorce ${ }^{28}$. A esto hay que sumar una cifra imprecisa de muertos en la ciudad -no menos de diez a fines de 1895 (S, f. 4vta) - para completar el resultado del plan civilizatorio.

En realidad, las "políticas indígenas" del gobierno y de los salesianos habían sido antecedidas, y serían des-bordadas, por la colonización ganadera. El reclutamiento de servidumbre fueguina se había efectuado en Tierra del Fuego desde la instalación de las primeras estancias y al margen del asilo salesiano donde se firmaba -día a día, en los registros misioneros- la extinción. Cuando Alexander Cameron, empleado de la SETF y encargado reo por dirigir la captura de los deportados, se reservó en la isla los que necesitaba ${ }^{29}$, reproducía una práctica ya existente. "Indio" no era entonces una categoría etnológica, sino una operación pre-legal que, indefiniendo la humanidad de una población, aseguraba el poder de administrarla. Sólo así pudo prometer el mismo Braun al presidente de la compañía que "si podemos capturar indios este invierno, intentaré guardar una niña para enviársela"30.

Sobre el número de "repartidos", "atrapados" o "de-portados", Martín Gusinde, el más importante antropólogo fueguino, creyó "casi imposible hacer una estimación", y eso que consideraba sólo a "las familias más pudientes", entre las que "se impuso la 'moda' de acoger 'un niño selk'nam' " (Gusinde 1990:150). Pero no sólo se trató de los pudientes. Por toda la isla, antes y después de 1895, se practicó el secuestro o la adopción forzada de servidumbre. Durante la primera expedición científica argentina, en 1886, Ramón Lista quiso procurarse un baqueano en San Sebastián, lo que produjo un enfrenta-miento con 28 muertos. Mujeres y niños fueron secuestrados, en una escena semejante a la de Punta Arenas diez años después ${ }^{31}$. En la comitiva viajaba uno de los primeros etnógrafos de la isla, el médico Polidoro Segers quien, "cuando volvió a Buenos Aires, trajo para el servicio doméstico a un matrimonio haush, Keppenau y Háuseme," que más tarde "desaparecieron sin dejar huellas" (Belza 1974:291).

También algunos funcionarios públicos se procuraron sirvientes. Domingo Canales, nombrado "Protector de Indios" por Señoret -fugaz empleo creado para fiscalizar a los misioneros-, tuvo a cargo "un muchacho de diez años" 32 . Tal como el que reclutó, un año antes, el comisario argentino, Ramón Cortés, durante una persecución de ladrones de ovejas por la costa atlántica ${ }^{33}$. En los primeros años de la colonización, la policía asistía y dependía de los ganaderos, al punto de confundirse Estado y estancia. John McRae era administrador de la estancia Gente Grande, que contaba entre sus socios al cónsul Stubenrauch, y fue el primer funcionario "en calidad ad-hoc" (Martinic 1981:74) del gobierno chileno. "Él en persona había muerto algunos indios", según Vicente Traslaviña, antiguo minero y baqueano, y "que ahora cinco años [1891]" había visto a McRae volver "de una excursión al interior de Gente Grande" con

...tres niños indígenas, un hombre y dos mujeres, los cuales se distribuyeron de la manera siguiente: el varón quedó en poder del mismo McRae; una de las mujeres en casa del señor Stubenrauch y la otra mujer se le remitió a don Ramón Portas; que el primero murió de enfermedad natural y los otros dos existen en esta ciudad $^{34}$ [Punta Arenas] en las casas indicadas; que en aquella ocasión preguntó si para traer esos niños habían ultimado a sus padres; el señor McRae contestó negativamente diciendo que los habían encontrado solos. (S, f. 156-156vta)

Traslaviña era uno de los buscadores de oro en torno a los cuales había surgido Porvenir $(1894)^{35}$. Rodeados de estancias, los primeros porvenireños se beneficiaron de los 
huérfanos que dejaban las cacerías y que se encontraban en la vecindad del pueblo. El mismo Traslaviña había ofrecido a otro accionista de la SETF "una chinita de ocho edad" hallada por su sobrino ${ }^{36}$ "cerca de Bahía Gente Grande [...] casi moribunda por el hambre y la sed" ${ }^{37}$. Otros vecinos decidían, en vista de la escasez, producir su propia servidumbre no entregando los niños, sino invirtiendo en criarlos. En 1893 José Cusmanich dijo haber encontrado "en las montañas de Boquerón, Tierra del Fuego, una pequeña criatura que no podría contar más de tres o cuatro años de edad", que según él "había sido abandonada por los indígenas", aunque agregó que al verlo, "huyeron a toda prisa". Cusmanich se quejaba ante gobernador porque había criado al muchacho "con cariño paternal" y sin todavía haberle "prestado servicio", el subdelegado Alfaro, "haciendo uso de la fuerza pública", lo "arrebató de mi casa", entregándoselo "a un vecino de Porvenir llamado Arturo Niño [expolicía]" ${ }^{38}$.

Funcionarios y pobladores ${ }^{39}$ disputándose los sobrevivientes de la colonización señalan los distintos estratos sociológicos (estanciero, misional, policial, etc.) y planos morales (indígena, infantil, animal, etc.) en que ésta se desplegó, así como la diferente trayectoria de estos huérfanos respecto de los niños que acabaron -en el doble sentido de conducidos y muertos- en la Misión: producción privada de servidumbre, en el primer caso; política de conversión de Indios en Obreros cristianos, en el segundo. En este sentido, las huellas civiles y la memoria local de las adopciones en Porvenir ofrecen pistas sobre el destino doméstico de quienes escaparon a la Misión, y a su registro de la extinción, como la servidumbre repartida en Punta Arenas.

Según el recuerdo de un descendiente de José Covasévich - "prestigioso ciudadano a quien Porvenir debe mucho de su progreso" familia, "nuestro pequeño indígena" que "habría crecido como un hijo" aunque

"conservando varios instintos primitivos que eventual-mente serían su perdición, como la tendencia a comerse las velas y los jabones que le gustaban mucho [...] Con quién jugaba, con quién compartió sus penas y si es que le enseñó algunas palabras de su gutural idioma a alguno de los tíos mayores, etc, creo que son detalles olvidados hace mucho tiempo. La historia no termina bien [...]: el aborigen no se domesticó mucho. Creció como un adolescente orgulloso y de mal carácter que hoy pasaría piola, que se molestó un día con el propio Simón [Cvitanic]. Hombre de pocas palabras, para expresar su disgusto le puso un cuchillo al cuello, quizás como amenaza, tal vez con la idea de cortárselo. En otra versión, fue sólo un intento de estrangulamiento. Si tuvo razón o no en ofenderse tanto, ya no es posible saberlo. Lo que es seguro es que al Abuelo [Covasévich] no le gustó esta agresión que estimó exagerada y lo echó de la casa. [...] Y nunca más se supo de él. Ni de los onas en general. Ni menos de su posible, y con seguridad díscola, rama de Covasévich patagónicos aindiados" (Covacevic 2010:16-17).

Las resistencias y fugas a la servidumbre, que también registra el Sumario o la crónica de las misiones subrayan el carácter inhospitalario de las adopciones. La domesticación entendida como producción de servidumbre- debía insistir en el salvajismo del huésped -hasta en el mito familiar-, como distancia afectiva para someterlo. Y también para obviar las responsabilidades civiles de un tutor. Esto explica que el subdelegado de Porvenir tuviera que cerrar la escuela "por falta de alumnos, ya que las personas que tienen a su cargo los indios Ona, se negaron en aquel tiempo a darles educación", pues "los tenían ocupados en los quehaceres domésticos"41. civiles, y hasta la misma prensa genocida sugería "a las familias que tienen en su poder 
niños o adultos fueguinos la conveniencia que habría en inscribirlos en la oficina del registro civil", ya que "pueden más tarde tener intereses propios, constituir una familia, etc." ${ }^{2}$. Así descubrimos, individualizados, a "Pedro Ona Covasévich" y "Luis Ona Sambelich" demandando hijuelas de tierra ${ }^{43}$, tal vez como parte de una estrategia de sus tutores ${ }^{44}$ ("Luis" te-nía sólo diez años). Como fuese, la aparición del nombre propio, conservando todavía la marca colonial "Ona", se distinguía del Indio como especie anónima, o anonimal, producida por la colonización.

Pedro Covasévich" cruzó la frontera, fue gendarme en Río Grande y en 1902 figura como baqueano e intérprete de una expedición científica ${ }^{45}$. "Luis Sambelich", siguiendo el oficio de su tutor, trabajó embarcado y también escapó a la servidumbre, pues compareció en febrero de 1904 ante el juez de Punta Arenas por un robo de cueros en la ciudad. Un extraño azar hizo que ese mes se dictase sentencia en el Sumario, sin la versión de las víctimas, y hace ahora que la declaración de "Sambelich" adquiera una función testimonial:

No conozco el apellido de mi madre a quien no conocí, soy chileno, tengo diez y seis años de edad, soy soltero, de profesión marinero, no sé leer ni escribir y es la primera vez que he estado preso ${ }^{46}$.

\section{Anonimato y traducción}

El reducto infantil en el que se ubicó a las víctimas en el Sumario, sin posibilidad de declarar, de representarse a sí mismas, tuvo una posibilidad de evasión. En febrero de 1896, el juez solicitó a Señoret "intérpretes oficiales para comunicarse con los indios fueguinos que figuran [...] como ofendidos" ( $\mathrm{S}, \mathrm{f} .186)$. El gobernador contestó que "le sería imposible" y argumentó que las relaciones entre "la población civilizada del territorio" y "los indios onas" habían sido "nulas o escasas" y "no ha habido tiempo ni ocasión para que algún indígena se familiarizara con el español o, recíprocamente, para que un individuo que posea el castellano llegara a poder expresarse en ona" ( $S$, ff. 188-189vta). No sólo obviaba la existencia, hacía siete años, de la misión de Dawson (y hacía tres, de La Candelaria) sino la más antigua presencia de la familia Bridges en el canal Beagle ${ }^{47}$. "Aunque es verdad que existen en Punta Arenas niños onas adopta-dos por algunos vecinos", agregó - develando de paso "adopciones" anteriores a 1895-, "sucede siempre que olvidan el idioma nativo o no tienen un desarrollo de ideas suficiente para servir de intérpretes" ( $S, 189 \mathrm{vta})$. Ante las excusas, los misioneros ofrecieron una lista de intérpretes ${ }^{48}$ que obtuvo, por sola consideración un "téngase presente" del juzgado.

En la lista figuraba "Calafate", "Kalapacte" o "Kalapaten", uno de los fueguinos enjaulados en la Exposición Universal de Paris en 1889, que se había fugado de ella, viajado por Francia y luego embarcado en Liverpool, desde donde volvió a Punta Arenas en 1890. En el viaje de regreso, y cuando "Calafate" rondaba los doce años, coincidió en Montevideo con el salesiano J.M. Beauvoir. Éste lo obtuvo como criado con la ayuda del antecesor de Señoret y disputándoselo a la misión anglicana ${ }^{50}$. Durante quince años no sólo realizó tareas domésticas sino que (in)formó la futura etnología fueguina, "contándome gran parte de la Historia [sus Memorias] [...] y en modo especial sirviéndome de Lenguaraz (intérprete) y ayudándome a componer el diccionario que después en compañía de los otros misioneros pudimos formar" ${ }^{51}$. 

mensuales)" y "con su indianidad y habla" fue clave en los comienzos de las misiones pues "buscó y trajo muchos paisanos suyos" 52 . En una ocasión, realizando este trabajo en los alrededores de La Candelaria, no se tuvo noticias suyas y después de tres meses "se lo encontró en un campamento de indios onas, ya semi desnudo y tan bien avenido con su nueva vida que no pensaba regresar a la misión". Parecía así repetir sus fugas de la Historia - de la jaula parisina, de La Candelaria-, fugas como las de "Jemmy Button" (capturado por Fitz Roy) o "Pedro Ona Covasévich"; aunque también sus voluntarias reapariciones pues, a comienzos de 1895, "se logró convencerlo y [...] ahora está de vuelta en Punta Arenas" ${ }^{3}$. De este modo, "Calafate", "Kalapacte" o "Kalapaten" se tradujo e interpretó en varios contextos ${ }^{54}$. lenguaraz disponible entonces en la ciudad, "la india Chonga o Covadonga que vive en la casa del señor Stubenrauch [...] donde ha sido educada, comprende y habla el español y el alemán" (S, f. 189). Según el recuerdo de José Perich, "Covadonga" fue obtenida por el cónsul en 1885, en la región de El Páramo, "aprendió a leer y escribir" y "viajó con la familia Stubenrauch a Alemania" donde "hizo un curso de 'servidumbre' durante 5 meses" 55 (Perich Slater 1995:147). A pesar de su civilización, para Señoret "Covadonga" sólo era "capaz de comprender y expresar ideas muy limitadas" y como además "estos indígenas se resisten tenazmente a hablar entre ellos delante de extranjeros" ${ }^{56}$, cuando desembarcaron los deportados de 1895, "fue forzoso dejar a la Chonga sola con ellos y obtener después de ésta, poco a poco, en los días sucesivos, algunas cortas observaciones sin valor" (S, ff. 189vta-190).

Si la narración de Señoret insistía en el Indio anonimal, Perich imagina tácticas para la "muy taimada" (S, f. 54) "Covadonga", afirmando que "enviaba al Cacique Felipe (t7 $^{57}$ tod las noticias que para él tenían interés, escuchadas en las tertulias de ganaderos en la casa Stubenrauch, muy especialmente las diligencias que se hacían para capturarlo" (p. 148). La reserva, el secreto y su traducción, combatían, de este modo, la extinción. Por otra parte, mientras que Señoret descartaba los intérpretes, el cónsul ya hacía traducciones a su favor, como cuando "por medio de esta misma muchacha", consultó "a los indios sobre sus necesidades", interpretó que estaban "muy complacidos con el lugar donde se encuentran actualmente sus hijos". Esto lo constató "personalmente, pues a mi cargo tengo tres muchachas que sus padres vienen a verlas continuamente" ( $S$, f. 17vta).

La variedad de criadas de Stubenrauch ofrecía no una sino varias traducciones. Y también malos entendidos, como la misma "Covadonga". Quizás fuera la niña que le procuró McRae al cónsul hacia 1891 (ver arriba su declaración), o tal vez ésta fuese otra de sus criadas, cuya muerte reseñó Maggiorino Borgatello. Es difícil saberlo porque el misionero, invirtiendo la operación del Sumario, dejó en el anonimato a "un acaudalado alemán, cónsul en Punta Arenas, protestante de religión" que vivía con su esposa sin hijos y "resolvió entonces adoptar [...] a una hermosa niña india Ona", la cual tenía "diez años más o menos" (la misma edad que indica Perich Slater 1995:147). No sabemos si el ocultamiento de "Stubenrauch" alcanzó también a la criada, pues aunque aprendió los mismos idiomas que "Covadonga" y viajó igualmente a Europa, no la llamaron así sino que "se le impuso el nombre de América" (Borgatello 1924:33). Según Perich Slater, Borgatello ofició el funeral de "Covadonga" en Punta Arenas; según el misionero, "América" estuvo convaleciente en la ciudad pero fue conducida a Dawson donde habría muerto a los 18 años, y no a los 25, como la "Covadonga" de Perich Slater. La tuberculosis 
comunica los dos relatos, y también otro malentendido: en el hospital, Borgatello le aconsejó a "América" que "pidiera al Señor le diese resignación" para que "sufriendo algo por su amor" pudiera "ganarse el Cielo": "Ella, empero, nada comprendía. Nadie le había hablado de Dios ni de una eternidad feliz o desgraciada. No conocía qué fuera la oración y creía que todo se acaba aquí con la muerte" (p. 35)

"Covadonga", replicada o traducida en "América", fue parte de las Florecillas silvestres, el libro ejemplar para jóvenes de "países civilizados y de padres cristianos" en el que Borgatello narró las muertes de algunos niños de la Misión ${ }^{58}$ : "florecillas nacidas en un terreno inculto, desierto, [...] sin los cuidados de solícitos jardineros" que, no obstante, llamados "por la divina gracia, correspondieron a ella con todo el entusiasmo de los santos" (Borgatello 1924:9). La visión cristiana que se proyectaba a la juventud civil se alimentaba de las visiones que los "salvajes convertidos" habían tenido en la agonía de tuberculosis y sarampiones. Así, "América", "postrada en la cama [...] me relató un sueño misterioso [...] en el cual había visto a María Auxiliadora rodeada de Ángeles, quien la había invitado a ir con Ella al Cielo" (Borgatello 1924:37). El sueño o la visión comunicación pura sin traducción - no eran extraños a la metodología salesiana ${ }^{59}$, tanto más cuanto que las misiones patagónicas se habían proyectado, como se sabe, a partir de un sueño de Don Bosco:

¡No pocas fueron las muertes semejantes a esta que yo presencié entre estos salvajes convertidos! Causaba envidia verlos partir de este mundo [...] ¡Bien recompensadas son las fatigas de los misioneros con la salvación de almas tan bellas y queridas a Dios! ¡Bien empleadas son las limosnas que con su dinero concurren a una obra tan grande y santa! (Borgatello 1924:38)

Borgatello había activado la escritura del Sumario don-de los salesianos arriesgaban perder la tuición de la infancia y, años después, representaba su muerte alucinada como la efectividad del trabajo misionero. Escribiendo la muerte sagrada, haciéndola envidiable a los jóvenes, continuaba la tarea. "Viéndonos impotentes para detener el golpe fatal que acabaría con su cuerpo", escribió también Beauvoir, se trataba de "salvar siquiera la parte mejor de ellos, es decir su espíritu" (Beauvoir 1915:V-VI) ${ }^{60}$. En ese sentido, si el Sumario había negado la Ley a las víctimas, impidiendo su traducción en el proceso, los salesianos ocupados del espíritu de los sobrevivientes, los excluyeron de la historia. Ambos gestos preparaban -el texto de- la extinción. Pero la apropiación/alteración de ese texto, su traducción, desafió la extinción en su propia escritura agónica, como cuando "América" resistió a Borgatello creyendo que todo se acaba aquí con la muerte. O cuando en las Memorias de Beauvoir se entrometió un "modo curioso" de "Calafate": la decisión que tomó ante su tuberculosis. En la isla Dawson, hacia 1905, "Calafate" decidió que iba a morir:

Un día que pasando por la carpintería vio al hermano Santiago que preparaba dos ataúdes para dos Indios que acababan de fallecer y preguntando para quiénes eran, luego añadió: "hágame uno también para mí". Por supuesto, el hermano no se dio por entendido. Pero el buen Calafate reiteró e insistió su pedido, diciendo que él mañana habría muerto. "No diga eso", le gritó el hermano, "tu ser joven, no estar enfermo, no morir". "Sí, sí”, insistió Calafate, "yo mañana morir". "Te repito", dijo el hermano, "Dios sólo saber cuando morir". Pero Calafate insistió, "yo morir mañana, tu hacerme el cajón". "Bueno", para sacarse la molestia le dijo el hermano, "ponte allí derecho, cerca de estas tablas", las que estaban allí en el taller. Él se puso bien arrimadito y tieso y para satisfacerlo de veras, le tomó la medida y se lo hizo. Acabado, para medírselo si estaba bien, se puso adentro 
sonriente: “muy bien", cuando lo vio concluido, "estar muy bien". Quién lo creería; al día siguiente de veras había muerto ${ }^{61}$.

\section{El límite de la infancia}

Por debajo de la ley y por fuera de la historia, la vida salvaje, lejos de extinguirse, se propagó como sentido colonial $-\mathrm{y}$ no nativo- en el que crecieron tanto la economía regional como las instituciones nacionales. El Sumario es una prueba del trabajo de anonimato que escribió la extinción, del interés salesiano en controlar-la, pero, al mismo tiempo, de la domesticación priva-da que, al margen de la política misionera, la evitó. El destino singular de los adoptados en Punta Arenas, y de todos quienes, secuestrados o no, se disolvieron en la servidumbre de la joven burguesía, es el de quienes sobrevivieron alejándose de la especie "Indio", del anonimal que se extinguió con las misiones. Dawson cerró en 1911 y La Candelaria conservó todavía algunos sobrevivientes; los "últimos", que la antropología - de Gusinde a Chapman - mantuvo como su propio re-ducto para salvar siquiera la parte mejor de ellos, no ya "el alma" sino la "cultura".

La producción colonial de la vida salvaje puede leerse mejor desde la situación de quienes no invirtieron en servidumbre. Era la situación de los empleados de las estancias, y en particular, de los que eran aislados en puestos alejados del casco administrativo (Bascopé Julio 2008:38-39). Los puesteros vigilaban los alambres de las incursiones de los cazadores fueguinos $\mathrm{y}$, ejerciendo de policías - por cesión de los gobiernos a los estancieros-, los enfrentaban. Contratados especialmente en soltería, los puesteros no se repartían los niños -que, en general, entregaban a sus patrones-, sino las mujeres. Estas relaciones, de las que resultaron muchos "matrimonios a la fueguina" e hijos bendecidos por los misioneros ${ }^{62}$, constituyeron el estrato sociológico, caza-dores frente a cazadores, en que se jugó efectivamente el avance de la colonización estanciera.

Si en las estancias no abundaban las mujeres, más escasos eran los niños. Las condiciones de vida de los puesteros se asemejaban, no obstante, a las descripciones de los Indios ${ }^{63}$, y en particular a la situación de los adolescentes klóketen, ampliamente tratada por la etnografía fueguina. Klóketen marcaba la situación en que los cazadores adultos mantenían a los jóvenes antes de acceder al secreto -la dominación de las mujeres-cuya revelación completaba el pasaje a la adultez masculina. Klóketen era un tiempo de preparación en el que los iniciados, como los puesteros de las estancias, permanecían aislados del grupo, soportando los rigores físicos de la caza ${ }^{64}$. De esta forma, los adultos distinguían el estadio pre-histórico o infantil del iniciado así como la animalidad de las mujeres -también ignorantes del secreto-, garantizando su poder y reproduciendo las asimetrías de la vida social ${ }^{65}$.

En el rito, el momento de pasaje a la adultez era pre-cedido de una escena de terror que los adultos representaban a los jóvenes y las mujeres. Del mismo modo, este poder de distinguir la prehistoria se ponía en juego cuando los puesteros-klóketen, salidos de su aislamiento juvenil, entraban en el vértigo del enfrentamiento con los cazadores fueguinos. Éstos, evidenciando lo que estaba en juego, "hacían huir a mujeres e hijos" ${ }^{66}$. Los puesteros aseguraban con rifles el carácter teatral de la escena, capturaban el botín y alcanzaban la adultez. A veces las mujeres discutían su estatuto de botín y cambiaban una banda de cazadores por otra, fugándose con los puesteros sin necesidad de enfrentamiento. Esta decisión confirmaba lo que podíamos suponer: que las mujeres 
podían representarse en el rito como ignorantes del secreto - la historia- que las subordinaba (Bridges 1949:424-425) ${ }^{67}$.

No por casualidad, junto a la lista de intérpretes que en 1896 ofrecieron al juzgado, los salesianos solicitaron "hacer declarar a todos los empleados de las diversas estancias". Observaron que éstos, como los jóvenes klóketen ante el terror, habían presenciado las "graves tropelías" cometidas en Tierra del Fuego. Pero "no figurando en este juicio los misioneros [...] como querellantes ni ofendidos", el juez contestó que "no ha lugar" ( $S$, 243-243vta) y estos testimonios, como los de las víctimas, tampoco pudieron representarse en el Sumario.

Tratándose del límite entre infancia y adultez, entre vida salvaje y reglas sociales, se comprende el interés antropológico en "la fiesta Klóketen" y la importancia de su correcta descripción para la traducción de la "cultura". También se entiende la decepción de Gusinde cuando vio sus impurezas, teniendo que aportar él mismo "muchos objetos importantes [que] no habían sido prepara-dos" (Gusinde 1990:161). Los problemas para representar al Indio coincidieron con los problemas para tenerlo bajo tuición: las "procaces bravatas antirreligiosas" que escuchó el antropólogo, indicaban fugas de la misión y contactos con la "peonada de la Isla" que tendían a "des-orientar a los indios". Remiten igualmente a la forma del escándalo que, amenazando la tuición salesiana, inició el Sumario. Tanto más cuanto que "en los últimos años se va repitiendo en la choza Klóketen, que algún hombre se permita palabras indecorosas y toqueteos impúdicos de los candidatos"68 (Gusinde 1990:163).

Gusinde culpaba a la colonización de haber corrompido el klóketen ("la europeización embruteció al indio"), y al "agotamiento de su fuerza vital" agregaba "la decadencia moral" que "no sólo no pueden detener la extinción inminente, sino que la apuran" (ibid). En realidad, quienes se fugaban de la misión escapaban a la vez de la extinción y de la antropología, reductos de pureza -religiosa y cultural- alterados con los "chistes lúbricos", las "conversaciones obscenas" y hasta las "revistas ilustradas" con "fotos de desnudos" que, como "impudicia repugnante", circulaban por los puestos de "las estancias de los europeos". En fin, incorporados a la vida salvaje de las estancias, "algunos muchachos jóvenes" se relacionaban, como cualquier puestero, "con mujeres europeas de mal vivir" (p. 158). Un mismo terror comunicó al misionero y al antropólogo: la intromisión de la historia como límite de la infancia.

\section{Extinción}

Bastantes años después de estos tristes acontecimientos, todavía un viejo puntarenense, Jesús Ossorio [sic], dueño de la 'Estancia Palomares' (Río Verde), y que falleció en 1936 a la edad de 76 años, recordará que él mismo se hizo cargo de un niño indio de siete años de edad, el que mantuvo hasta que cumplió 14 años y que desapareció llevándose un caballo que le había regalado el propio Ossorio... Para éste, se había fugado a la Argentina. (Gómez Tabanera 1986:969).

Los documentos que hemos conectado radicalizan el problema del Indio fueguino indicando los márgenes en que ocurrió su extinción. Si en tanto categoría, la paradoja de "Indio" es ser a la vez requisito y resultado de una operación colonial, no es menos cierto que la utilidad de su empleo crece con su imprecisión. Así, el Indio que se pacificó en la Araucanía, el que se conquistó en el desierto argentino o el que se extinguió en la Tierra del Fuego, traducen una misma situación: la reducción de un territorio y la puesta bajo 
tuición de los sobrevivientes. Pero mientras en el caso mapuche el Estado atribuyó títulos de tierras cuya marginalidad y pobreza produjeron la vida salvaje que estudiarían los antropólogos, en el caso fueguino, a falta de Estado, serían las estancias las encargadas de producirla. En esto fueron asistidas por los misioneros quienes, asilando a los sobrevivientes de las cacerías, registraron más tarde su extinción.

Hemos intentado demostrar, sin embargo, que la sobrevivencia no se redujo a la misión, sino que, por la vía del reclutamiento de servidumbre doméstica -paralelo al de la apropiación de mujeres-, ingresó a la historia civil de la población. Sobrevivencias que, fuera del poder salesiano e inarchivables como "indias", no pudieron, por lo tanto, extinguirse.

Anexo I. Nómina de las personas, que tomaron a su cargo Indios Ona, llegados de la Tierra del Fuego en el mes de Agosto de 1895, en conformidad con las condiciones y reglas establecidas por la Comisiva [sic] de Indígenas:

\begin{tabular}{|l|l|l|l|}
\hline & & & \\
\hline A. Ladouch & 1 & A. Marcou & 1 \\
\hline Francisco Suarez & 2 & Exequiel Garrido & 1 \\
\hline Filomena Vasquez & 1 & Julia V. de Gomez & 1 \\
\hline Ramon Silva & 2 & José Audicio & 1 \\
\hline Alberto Barra & 1 & Luis Acevedo & 1 \\
\hline R. Stubenrauch & 3 & Antonio Gonzalez & 1 \\
\hline Z. Tapia & 1 & Antonio Oyarzo & 1 \\
\hline Luis A. Tapia & 1 & Margarita Diaz & 1 \\
\hline Benito Manso & 1 & Maria Cardenas de Diaz & 1 \\
\hline Fernando Ramirez & 1 & Rosario Andrades & 1 \\
\hline Adrian Ponte & 1 & Manuel Anto ${ }^{\text {Ruiz }}$ & 1 \\
\hline Pedro [Bahula?] & 1 & José D. Aravena & 1 \\
\hline José Riverós & 1 & Anjela Ballester & 1 \\
\hline Feliciano Salasar & 1 & Elvira Ballester & 1 \\
\hline A. Wehrhahn & 1 & Juan A. Vargas & 1 \\
\hline Ignacio Diaz & 1 & Luis Bordet & 2 \\
\hline
\end{tabular}




\begin{tabular}{|l|l|l|l|}
\hline Elena Telles & 1 & Dolores Vargas & 1 \\
\hline José Picore & 1 & Juan [Irañeta?] & 1 \\
\hline Ponton Yungay & 4 & Maria Sepulveda & 1 \\
\hline Francisco Arnau & 1 & L J'Anson & 1 \\
\hline Damian Diaz & 1 & José Martes & 2 \\
\hline Luis Diaz & 1 & Indio Mulato & 4 \\
\hline Vapor Yañez & 2 & & \\
\hline Crucero Pr. Errasuriz & 3 & & \\
\hline Goleta Marta Gale & 2 & & \\
\hline Cuartel de Policia & 13 & & \\
\hline
\end{tabular}

51 Este anexo está tomado del Sumario por vejámenes inferidos a indijenas de Tierra del Fuego, pag.190 y 191. Archivo Nacional (Santiago), fondo "Criminales Magallanes", vol. 75, 2-12-1895.

\section{Anexo II. Solicitud de José Cusmanich al Gobernador de Magallanes:}

Hace unos cinco años encontré en las montañas de Boquerón, Tierra del Fuego, una pequeña criatura que no podría contar más de tres o cuatro años de edad. Ésta había sido abandonada por los indígenas que habiéndome visto, huyeron a toda prisa. Desde ese momento el niño abandonado quedó en mi poder, habiéndolo criado con cariño paternal y dándole todo lo necesario para su subsistencia. En la actualidad es un muchacho como de ocho anos de edad, y todavía no me ha prestado servicio alguno por razón de sus cortos años. A pesar de los cuidados y de los gastos que he debido hacer para la crianza de este indígena, el Sr. Subdelegado de Tierra del Fuego, haciendo uso de la fuerza pública, arrebató de mi casa el citado muchacho y lo entregó a un vecino de Porvenir llamado Arturo Niño, quien lo recibió en su casa sin más trámites.

Este acto entraña un ataque injustificable a mis legítimos derechos, por cuanto no hay razón alguna que pueda asistir al Sr. Subdelegado para obrar de esa manera arbitraria. Yo no puedo admitir que se me arrebate un niño que lo considero como a mi hijo y que durante cuatro años ha estado en mi poder. Los cargos que el Sr. Subdelegado me ha hecho no pueden pesar en el justo criterio de U.S., pues no escapará a U.S., que un niño de corta edad, que todavía no presta servicio, es inquieto y juguetón. Su comportamiento en el nuevo poseedor será el mismo y mientras tanto yo perderé mis sacrificios y mis gastos. Deseo que U.S., se penetre de cuánto ha herido mis sentimientos este despojo, para que inspirándose en la justicia, se sirva U.S ordenar me sea devuelto este niño.

Protesto ante U.S. de que en mi casa no hay malos ejemplos, es respetada por todo el vecindario y he educado a mi muchacho con los medios de que se puede disponer en esta 
tierra, pues posee el idioma del país y el mío. No debo dejar de hacer presente a U.S., que las relaciones del Sr. Subdelegado con mi casa comercial dejaron mucho que desear, y este hecho revela el origen de esa medida, que no es otra cosa que una perfecta hostilización a mis intereses.

En vistas de estas consideraciones ruego a U.S. se sirva oír mi queja y ordenar se me devuelva el niño que he prohijado.

Porvenir, Mayo 1ro, de 1898

Este anexo está tomado de la Solicitud de José Cusmanich al gobernador de Magallanes (Mariano Guerrero Bascuñán), Porvenir, 1-5-1898, Archivo Nacional (Santiago), Gobernación de Magallanes, vol. 21: "Subdelegación de Tierra del Fuego" (STF).

Punta Arenas, Febrero 7 de 1896.

\section{BIBLIOGRAPHY}

Aliaga, F. (1984). La Misión en Isla Dawson (1889-1911). Santiago: Universidad Católica.

Báez, C. (2009). Más allá de las imágenes. Fotografías de fueguinos y patagones en contextos de exhibición (1878-1898). Tesis doctoral en historia. Santiago: Universidad Católica.

Barclay, W. S. (1904). The Land of Magellanes, with Some Account of the Ona and Other Indians. The Geographical Journal 23 (1), 62-79.

Bascopé Julio, J. (2008). Pasajeros del poder propietario. La Sociedad Explotadora de Tierra del Fuego y la biopolítica estanciera (1890-1920). Magallania 36 (2), 19-44.

Bascopé Julio, J. (2010a). Antes de la Ley. Salvajismo y comercio sexual en Tierra del Fuego y Patagonia austral, 1884-1920, en: Pavez, J. y Kraushaar, L. (Eds.), Capitalismo, trabajo y violencia, San Pedro de Atacama: IIAM-UCN, en prensa.

Bascopé Julio, J. (2010b). Desvíos salesianos. La expedición de 1906 y los misioneros volantes. Magallania 38 (2), 249-259.

Bascopé Julio, J. (2010c). Sentidos coloniales I. El oro y la vida salvaje en Tierra del Fuego, 1880 1914. Magallania 38 (2), 5-26.

Beauvoir, J. M. (1915). Los Shelknam, indígenas de la Tierra del Fuego. Sus tradiciones, costumbres y lengua. Buenos Aires: Talleres Gráficos de la Compañía General de Fósforos.

Belza, J. E. (1974). En la isla del fuego. Buenos Aires: Instituto de Investigaciones Históricas de Tierra del Fuego.

Belza, J.E. (1977). En la isla del fuego. Buenos Aires: Instituto de Investigaciones Históricas de Tierra del Fuego.

Borgatello, M. (1924). Florecillas silvestres. Torino: Scuola Tipografica Salesiana.

Braun Menéndez, A. (1985). Mauricio Braun: memorias de una vida colmada. Explicación preliminar, notas y epílogo por Armando Braun Menéndez. Buenos Aires.

Bridges, E. L. (1949). Uttermost part of the earth. London: Hodder \& Stoughton. 
Covacevic, N. (2010). La historia posiblemente exagerada del abuelo. Punta Arenas: borrador inédito.

Derrida, J. (2008). Séminaire La bête et le souverain. Paris: Galilée.

Fuentes Rabé, A. (1923). Tierra del Fuego. Valdivia: Imprenta Central E. Lampert.

Gómez Tabanera, J. M. (1986). El emigrante asturiano José Menéndez (Miranda de Avilés, 1846Buenos Aires, 1916), "Rey sin corona" de Patagonia y Tierra del Fuego (Chile / Argentina) y la extinción de los indígenas”. Boletín de Estudios Asturianos 119, 937-970.

Gusinde, M. (1990). Los indios de Tierra del Fuego. Tomo I. Los Selk'nam. Buenos Aires: Centro Argentino de Etnología Americana.

Holmberg, E. A. (1906). Viaje al Interior de Tierra del Fuego. Buenos Aires: Ministerio de Agricultura.

Malaurie, J. (2010). "Preface”, en: Aux confins de la Terre. Une vie en Terre de Feu (1874-1910),

(pp.9-25). Bruxelles: Nevicata.

Martinic, M. (1981). La tierra de los fuegos. Porvenir: Municipalidad de Porvenir.

Martinic, M. (1985). La Correspondencia del Gobernador Dublé con el Jefe Tehuelche Papon, Anales del Instituto de la Patagonia 16:41-43.

Payró, R. (1898). La Australia argentina. Excursión periodística á las costas patagónicas, Tierra del Fuego é Isla de los Estados, con una carta-prólogo del General Bartolomé Mitre. Buenos Aires: Imprenta de "La Nación".

Penazzo, N. (1995). Wot'n. Documentos del genocidio ona, T. II. Buenos Aires: Ediciones Arlequín de San Telmo.

Perich Slater, J. (1995). Extinción indígena en la Patagonia. Punta Arenas.

Sackel y Kramarencko. (2007). Colonizadores de Tierra del Fuego. Punta Arenas: Comercial Atelí [Imprenta El Magallanes].

Señoret, M. (1896). Memoria del Gobernador de Magallanes. La Tierra del Fuego $i$ sus naturales. Santiago: Imprenta Nacional.

Taussig, M. (1984). Culture of Terror-Space of Death. Roger Casement's Putumayo Report and the Explanation of Torture. Comparative Studies in Society and History 26 (3), 467-497.

Vidal Espinoza, H. (1993). A través de sus cenizas. Imágenes etnográficas e identidad regional en Tierra de Fuego (Argentina). Tesis de maestría en antropología, FLACSO-Ecuador.

\section{NOTES}

1. Human Rights and Equal Opportunity Commission, 1997. Bringing them home: report of the National Inquiry into the Separation of Aboriginal and Torres Strait Islander Children from their Families. Commonwealth of Australia, Canberra.

2. Expresión utilizada por el etnólogo Jean Malaurie en el prefacio a la reciente traducción francesa de la obra de Lucas Bridges, Uttermost Part of the Earth (Malaurie 2010:13).

3. “Más allá de la convergencia coyuntural de sus estrategias, misioneros y etnógrafos compartían un fundamento simbólico más profundo. El indio que buscaban y construían una y otros tenía muchos elementos comunes, como lo tenían también la misión de salvataje que unos y otros se imponían respecto a él" (Vidal Espinoza 1993:31). 
4. Cabe consignar que la relación entre los gobiernos argentino y chileno y los nómades patagónicos, en-marcada en la disputa fronteriza, tuvo más mediaciones políticas, como por ejemplo, las cartas que enviaba el gobernador a los caciques. Cf. Martinic (1985).

5. Recurriremos a la mayúscula y singular para remar-car el hecho colonial y no nativo de esta clasificación. "Indio" - aunque también "Indígena", "Salvaje" o "Bárbaro"- suprime la heterogeneidad sociológica de las poblaciones que describe. No tratándose aquí de una etnografía, Indio o lo Indio indicará la operación a través de la cual ganaderos, misioneros y funcionarios objetivaron un conflicto.

6. Navarro, Lautaro en El Magallanes, Punta Arenas, 15-4-1894. Un año después, el salesiano José Fagnano confirmaba al presidente chileno este interés:

"Esperamos que éstos [los niños] serán los peones de las grandes estancias que se establezcan en el territorio y así habremos cambiado a los enemigos de la civilización en factores y ayudantes del progreso", carta a Jorge Montt, 25-3-1895 (citado en Aliaga 1984:32).

7. "El padre Fagnano presentó una solicitud respecto a los Indios y acordamos dar $€ 1$ esterlina por cada Indio que enviemos a la Isla Dawson, y confío en que esto encontrará su aprobación. Creo que es la manera más barata de deshacernos de ellos, en lugar de dispararles, lo que es bastante censurable", carta de Peter McClelland, presidente del directorio de la SETF, al gerente Mauricio Braun, Valparaíso, 1-6-1895, Archivo Museo Regional de Punta Arenas (AMR), "Correspondencia Mauricio Braun". La de-portación a Dawson fue decretada "en forma oficial por el Ministerio de Relaciones Exteriores y Colonización el 2 de junio de 1898”, con la aclaración de que debía hacerse "de acuerdo con el Cónsul de Argentina" (Aliaga 1984:52).

8. Señoret tenía sospechas políticas de la labor salesiana, pues aun cuando ésta "tuviera por objeto propender a la civilización de los naturales, ella no podría satisfacer, desde el punto de vista nacional" dado que "los misioneros que se cambian de Dawson [...] a Río Grande [...] tienen que predicar a los neófitos indígenas acá el amor a la patria chilena y allá a la patria argentina. Esto es inaceptable" (Señoret 1896:36).

9. Acercándose, sin saberlo quizás, a la política australiana, sugirió la instalación de tres puestos mili-tares en la isla, encargados a la vez de vigilar y de transmitir modales, con un misionero franciscano a la cabeza (esta orden contrastaba, según Señoret, con el espíritu comercial de los salesianos; Señoret 1896:38). El gobernador pensaría también en las primeras estadísticas étnicas. Estableció la necesidad de llevar una cuenta de los indígenas ubicados en cualquier punto del territorio informando sobre la edad, sexo, nombre conocido o de bautizo, profesión, defunciones, nacimientos, matrimonios, etc., así como una lista con los indígenas que hubieran adoptado completamente los hábitos de la civilización, El Magallanes, Punta Arenas, 9-2-1896, p.2.

10. Sumario por vejámenes inferidos a indíjenas de Tierra del Fuego, en Archivo Nacional (Santiago), fondo "Criminales Magallanes", vol. 75, 2-12-1895.

11. El Juzgado de Punta Arenas había sido inaugurado dos años antes bajo la administración de Señoret.

12. En sus Memorias, Braun sostuvo que el gobernador fue quien "hizo efectuar un rodeo de indios [...] y los trasladó a Punta Arenas" (Braun 1985:135). No obstante, en el proceso admitió que la orden a sus empleados era perseguir a los "ladrones [de ganado] y encontrando indios sospechosos, los aprehendan y conduzcan a las casas del fundo" (S., ff. 169vta-170).

13. Leyendo el Sumario notamos que el "estado de completa desnudez" escandalizó a denunciantes y denunciados y apuró la caridad hasta que estuvieron "suficientemente vestidos para no ofender la moralidad pública” (declaración de José Contardi, $S$, f. 6vta y 7vta). Considerando, como hizo la denuncia al comienzo del Sumario, que "ellos en su tierra se abrigan con pieles de guanaco" y que éstas eran parte del botín de las cacerías humanas, era probable que las hubieran "perdido en su mayoría con estas aventuras" (El Chileno, 9-11-1895). El salesiano Borgatello acusaba al propio Señoret de haberse "apropiado cueros de nutria y de lobo por valor de trescientos pesos 
sacándolos a los indios que trajo [a Punta Arenas] el 'Toro' el 18 de septiembre de 1894", reprochándole su "exquisita caridad" al hacer pagar a la gobernación los "gastos que se habían hecho por ropas suministradas a los indios" (S. f.134-136). La escandalosa "desnudez salvaje" sería, de este modo, el resultado de un robo colonial de vestiduras.

14. Se publicó incluso que "los carniceros les ofrecen carne para ver cómo la comen cruda" (El Chileno, 9-11-1895). Lo cierto es que la precariedad general del proceso (cacería, deportación, hacinamiento, etc.) produjo la vida salvaje que se pretendía extinguir: "ví una mujer envuelta en una frazada, toda encojida, como una pelota, que casi no daba señal de vida y a su lado se le había puesto un pedazo de carne cruda; ¡parecía una broma! ¿Como iría á comer aquella carne, cuando no podía tragar agua, la cual por supuesto nadie se la pasaba? Ésta también murió dos días después" (declaración del salesiano Maggiorino Borgatello S. ff. 128vta-129).

15. Editorial de La Razón, Punta Arenas, 29-1-1894. Paralelamente, la inmigración predominante de hombres solteros para las faenas ganaderas había generado una escasez de mujeres que en Tierra del Fuego se resolvía en combates masculinos (Bascopé Julio 2010a). De ahí la baja cifra de hombres adultos en las capturas o que las instalaciones de Dawson, aparte de la iglesia, la casa de misioneros y los talleres, se redujese al "dormitorio de las niñas, de los niños y de las viudas" (Aliaga 1984:31).

16. Testimonio de Elías Micacich, conductor del barco (S, f. 82vta).

17. Las informaciones que apoyaban al gobernador se publicaban preferentemente en el diario $\mathrm{El}$ Magallanes.

18. En este contexto, el singular "contrato" que firmaban los beneficiados con niños -así como el acuerdo entre los salesianos y la SETF-, simulaba una "tuición consentida", borrando la violencia de la separación.

19. El Porvenir, Santiago, 4-12-1895, citado en Perich 1995:90.

20. Según el juez, Barra era la única persona imputable en el proceso, por haber ordenado una flagelación. Correspondió al reo Luis Gutierrez el trabajo de pegar "a un indio veinticinco azotes por no sé que falta que había cometido" y para ello "me dieron un rebenque con que se pega á los caballos [...] para pegarle al indio tuvieron que amarrarle las manos á un poste. Los azotes se los pegué a cuero vivo y como a los veinte que le había dado, cayó al suelo el indio como desmayado $\mathrm{y}$, sin embargo, el oficial me dijo que se siguiera pegando, pero yo me resistí. Puedo asegurar que al indio no se le pegó después que cayó al suelo" (f. 76vta). Barra murió durante el proceso y no pudo ser condenado.

21. Las testigos confirman la separación violenta, pero nada dicen de desmayos o rasgaduras, que sí figuran en otras declaraciones. De ahí que, para enfatizar el horror, Borgatello pareció mezclar testimonios o hacerse parte de rumores, como cuando reprodujo (f. 126) una historia de Clorinda Mancilla sobre un padre al que, por sus "señas", ella interpretó que "le habian comido a su hijito" (142vta). Las descripciones terroríficas existieron también en otros contextos de violencia (como la extracción del caucho en el Putumayo) y operaron en "la formación y difusión del imaginario colonial" (Taussig 1984:492).

22. Serrano agrega que los salesianos temían una disminución de sus "entradas" con la competencia de los franciscanos. Así "se comprende el por qué de la guerra al Gobernador de Magallanes y el por qué de la adulteración de tantos hechos que hacen aparecer al gobernador y a todo el pueblo de Punta Arenas como un pueblo de caníbales ajenos a todo sentimiento humanitario", El Magallanes, 16-1-1896, publicado originalmente en La Libertad Electoral, Santiago, 23-12-1895.

23. "El soberano y la bestia tienen en común el estar fuera de la ley" (Derrida 2008:38).

24. Así lo calificaba en una elogiosa reseña El Magallanes, 22-11-1896. Mulato había recibido años antes una concesión de diez mil hectáreas en la zona del río Zurdo.

25. "Rodríguez [Leoncio, accionista de la SETF y ministro de la Corte de Apelaciones] acordó que un ministro de la Corte en Valparaíso, Sr. Cruz, irá a Punta Arenas a ver cómo van los asuntos en 
el juzgado y corregir ese pequeño fraude de un juez [to put that little fraud of a judge straight]", carta de Peter McClelland (presidente de la SETF) a Mauricio Braun, Valparaíso, 21-1-1896, Archivo del Museo Regional de Punta Arenas, "Correspondencia Mauricio Braun". En la misma carta sabemos que Rodríguez había negociado con el gobierno chileno el envío de policía a Tierra del Fuego. MacClelland consideraba que así, "teniendo un hombre, un oficial de la ley, cualquier cosa que hagamos para defendernos de los ataques de los indios no podrá ser interpretada como homicidio".

26. El Magallanes, 11-3-1894. El diario fue fundado ese mismo año.

27. "Los indios traídos se descomponen así: Menores de un año: 24. De 1 a 15: 46. Hombres de 15 a 20: 22. Mujeres de 15 a 20: 33. Hombres de 20 a 25: 25. Mujeres de 20 a 25: 10 . Hombres mayores de 25 años: 4. Total: 164.", El Magallanes, 11-8-1895. Esta cifra total se alterna con la de 165 en la mayor parte de los registros. En diciembre del mismo año se "integraron" al campamento de Punta Arenas otros deportados, retenidos en la estancia Springhill: eran dieciséis (f. 44) o "dieciocho indígenas entre hombres, mujeres y niños" (f. 53). Si bien la imprecisión podría deberse a alguna muerte, subraya sobre todo el estatuto animal que permitió cazarlos ("de día estaban sueltos en el patio de las casas y de noche encerrados y custodiados por un individuo", ff. 44vta-45), así como el anonimato en que se los mantuvo durante todo el proceso.

28. "Indígenas enviados a la isla de Dawson desde Punta Arenas: Por Crucero Presidente Errázuriz - Febrero 8 1896. 21 hombres, siendo uno de 50 años, 15 de 23 a 30 i 5 de 35 a 40. 26 mujeres - 18 de 18 a 22 años 1 de 50 i 7 de 25 a 30. Por escampavía Cóndor Abril 27. 3 hombres de 20 a 25 años. 5 mujeres -3 de 20 a $25-1$ de 35.3 id de 30.4 niños hombres de 3 a 5 años. 2 niñas mujeres - 1 de 2 años 1 de 8.", Ministerio de RR.EE, Fondo Gobernación de Magallanes, vol. 8.

29. "Como supongo que todos los indios irán directa-mente a Punta Arenas, no reservaré aquí más que los que yo necesito, así es que si Ud. [Braun] necesita alguno, puede elegirlo en ésa" (carta de 25-7-1895, adjunto en S, ff. 203-206).

30. Carta a Peter McClelland, AMR, 2-06-1899. En carta de 11-09-1897, Mcclelland agradecía el envío de otra "indiecita [que] llegó bien y ha sido bien entre-nada y presumo que con tiempo se acostumbrará a nuestros modos".

31. La descripción fue escrita por Fagnano que acompañó a Lista previendo la fundación de una misión y extrañamente omitió en su crónica los enfrentamientos: “...las indias chillaban y forcejeaban para escapar. Las criaturas lloraban y no querían comer ni guarecerse bajo las carpas. Tuvimos que dejarlas afuera y en el suelo [...] Toda la noche exhalaron gritos de dolor..." (citado en Belza 1974:166).

32. Canales viajó a Dawson acompañado del niño, "con el objeto principal de ver si encontraba ahí a su madre; en efecto la encontró desnuda y sumamente flaca y esa madre llorando y conociendo por los in-formes del niño el tratamiento que le damos en la Colonia [Punta Arenas], me decía solamente: 'No deje aquí a mi hijo; no lo dejes' ", informe dirigido a Señoret, 22-2-1896, Archivo Nacional (Chile), Fondo Gobernación de Magallanes, vol. 8. Por la fecha de su relato, Canales parece poco objetivo.

33. No obstante, faltando los medios, el servicio no siempre podía mantenerse: "Mi equipaje y el mu-chacho indio lo he tenido que abandonar" (Penazzo 1995:243).

34. Más adelante, Señoret confirmará la existencia de niños en Punta Arenas antes de los 165 del Sumario.

35. Sobre el oro y el origen de la vida salvaje en Tierra del Fuego, ver Bascopé 2010c.

36. Vale la pena consignar que su sobrino, Emilio Traslaviña, fue muerto junto a otro empleado de la SETF en enero de 1896, cuando custodiaban a un grupo de fueguinos. Al igual que los 165, éstos habían sido capturados en las cercanías de San Sebastián pero, en el camino a la estancia Caleta Josefina para ser también deportados, se rebelaron contra sus custodios. Su tumba todavía puede visitarse en el cementerio de la estancia. 
37. "Traslaviña me dijo que sabía que a los padres y demás familia de la chinita los habían muerto. La chinita fue colocada por mí en el convento de salesianos en Punta Arenas, entregada a la Superiora. Le puse por nombre Aurora Orgueta y fue bautizada con este nombre" (declaración de Cruz Daniel Ramírez, S, f. 250). Ramírez fue un testigo clave en el Sumario pues, siendo parte de la SETF, le constaba que "los hacendados persiguen a los indios como animales por haberlos oído decir a todo el mundo en la Colonia” (op. cit). Había viajado a fines de 1894 a Tierra del Fuego para inspeccionar las instalaciones de la compañía, informando críticamente al directorio sobre la gestión de Braun (una copia del in-forme, fechado el 14-2-1895, y el resto de la polémica se encuentran en AMR).

38. Solicitud de José Cusmanich al gobernador de Magallanes (Mariano Guerrero Bascuñán), Porvenir, 1-5-1898, Archivo Nacional (Santiago), Gobernación de Magallanes, vol. 21: "Subdelegación de Tierra del Fuego" (STF). En su defensa, el subdelegado Manuel J. Alfaro desmentirá el buen trato de Cusmanich porque el mismo Alfaro "entregó a la policía al indio en completo estado de desnudez", STF, 19-7-1898. La solicitud de Cusmanich la adjuntamos íntegramente en los anexos.

39. Que entonces, y como Cusmanich, eran mayoritariamente inmigrantes austríacos provenientes de Dalmacia.

40. Y que en su momento "tuvo que luchar contra los indios aborígenes con inminente peligro de verse asesinado por ellos" (Sackel y Kramarencko 2007:35). Covasévich vino como minero, luego fundó la primera casa comercial de la isla y más tarde obtuvo una concesión de tierras, convirtiéndose - como el cacique Mulato- en estanciero.

41. Manuel J. Alfaro al gobernador de Magallanes (Carlos Bories), STF, 16-5-1899. En el mismo documento se adjunta un "Registro de los niños de 6 a 13 años de edad que existen en Porvenir y que pueden concurrir a la escuela" donde figuran al final, y distinguidos como "Indios Ona", los que estaban bajo tuición: "Linda del Oro" y "Chasque Boquerón” (11 y 12 años, respectivamente, vivían con John McRae), "Luis Ona” (10 años, con Jorge Sambelich) y "Vicente Mimiza” (10 años, con Pedro Mimiza).

42. “...todos ellos son personas adquiridas para la sociedad y como tales deben tener su estado civil. Algunos de ellos pueden más tarde tener intereses propios, constituir una familia, etc., y pueden necesitar este requisito legal. Por otra parte es una diligencia bien fácil de llenar y sin costo alguno. La ley de registro civil impone además esta obligación a los guardadores o tutores de indígenas", El Magallanes, 10-05-1896.

43. STF, solicitudes de 20-12-1899 y 13-1-1900, respectivamente (lo hacen junto a otros pobladores).

44. La falta de tierras para alimentar a sus animales amenazaba, por la misma operación que venimos in-dicando, con transformar en Indios a los migrantes porvenireños. En un documento de 1897, firmado por veintinueve vecinos (entre los que figuran José Cusmanich, José Covasévich y Jorge Sambelich), y que hemos citado en otro lugar (Bascopé 2010c), éstos declaraban que la población iba a "perecer ahogada entre los alambres de las concesiones ganaderas".

45. Se trató de la expedición de E. Holmberg y R. Lehman-Nitsche. El primero publicó una foto donde se lee: "Pedro Covasovich - Ona: guía" (Holmberg 1906:73)

46. "A los cargos que le hizo el juzgado contestó de una manera incoherente que era inocente de lo que él mismo se había confesado autor", en "Sumario contra Antonio Luchetti, Luis Zambelich, Luis Cayuli y Manuel Díaz por robo", 25-2-1904, Archivo Nacional (Santiago), Criminales Magallanes, legajo 123, n. 34, f. 12-12vta. Cabe indicar que Sambelich no pudiendo entre otras cosas precisar la fecha de los hechos "por no tener conocimiento ni nociones de los meses y de los días del año" (f. 4vta), será liberado porque, pese a declararse implicado en el robo, Luchetti afirmó que "el único culpable de este robo soy yo y no sé porqué el Indio Sambelich quiere hacerse cómplice [...] y creo mas bien que es un muchacho inocente que no tiene ninguna culpa", ff. $4-6$. 
47. En la misión anglicana de Ushuaia vivía desde 1871 el misionero Thomas Bridges y su familia. Desliga-do de la misión y convertido en estanciero tras la llegada del gobierno argentino, se asoció a partir de 1894 con los grupos cazadores perseguidos por los estancieros del norte para extender su actividad ganadera. Sus hijos - nativos de Tierra del Fuego- continuaron la empresa tras su muerte. El diccionario yamana-inglés legado por Thomas y la obra de su hijo Lucas (Bridges 1949) revelan que hubo personas suficientemente familiarizadas con la lengua fueguina como para ejercer de traductores. El caso de los Bridges, su singularidad respecto a colonos o misioneros, será tratada en la última entrega de los Sentidos coloniales.

48. "Como es muy posible que S.S. tropiece con la escasez de intérpretes, nos permitimos designar como tales a los siguientes indígenas ya civilizados que existen en nuestra Misión de Dawson y que pueden aprovecharse con tal objeto: Luis, Calafate, José fueguino, que hablan Ona y Alcalufe, Harris, algo inglés tambien; Ángel, Felipe, Jacinto, Juanito, Silvestre, Próspero, Julio y otros más si precisan, los cuales todos hablan castellano y Alacalufe, y entienden algo de Ona", carta al ministro en visita de 20-2-1896, adjunta en el Sumario (f. 243) y firmada en nombre de los “Misioneros Salesianos de Magallanes" por Juan Bernabé.

49. "Hijo de un jefe de la zona de Gente Grande, cuyo nombre era Kaleluly. Tenía un hermano que se llamaba Taarkn y un tío de nombre Hanich" (Báez 2009:150).

50. “Así fue, pues no obstante que el Pastor de la Misión Protestante inglesa de Ushuaia lo pretendiese también, llegando a Punta Arenas por medio del Gobernador del Territorio me lo hice entregar", en Memorias del Misionero Salesiano Don José María Beauvoir (copia mecanografiada del original), Turín, 1940, p. 6, Archivo Central Salesiano, Roma (ACS), fondo J.M Beauvoir, caja B210.

51. Ibid. Se trata del Pequeño diccionario del idioma fueguino-ona... que Beauvoir publicó en 1901 (Buenos Aires: Escuela Tipográfica Salesiana), sucedido por Los shelknam: Indígenas de la Tierra del Fuego (Buenos Aires: Librería del Colegio Pío IX, 1915). De la autoría de ambos libros no sólo fue excluido "Calafate" sino también otro misionero, Giovanni Zenone, quien le envió "más de mil locuciones onas que él recibió (pues están en su libro) y ahora veo que me asigna la centésima parte del producto de aquella obra", carta a José Fagnano, 23-1-1916, citada en Belza 1977:230.

52. Memorias..., p. 33.

53. El Magallanes, 28-4-1895. Además de mostrar la ineficiencia en la retención de los fueguinos, el artículo criticaba a la misión por no producir "hombres libres que gocen de los derechos que tienen, sino una recua de esclavos sin voluntad propia. Eso es rebajar la condición moral del individuo hasta transformarlo en un ser abyecto, sin criterio, sin noción del yo".

54. La fuga de Calafate dejó en evidencia no ya su "instinto salvaje", como pretendía Beauvoir, sino el salvajismo de los misioneros que, tras tres años de misión, aún eran ignorantes del idioma nativo: “¿Lástima que su idioma es cosa difícil de manejar y ellos con no poca dificultad pueden comprender el nuestro! ¡Cuánto bien podríamos hacerles si entendiéramos! ¡Que falta nos hace un intérprete! Esperábamos que Luigi Michele Calafate hubiera servido de ayuda, pero ¡oh, qué amargo desengaño! Nadie es profeta en su tierra, corresponde repetir. Primero dice no conocer más el indio; luego empezó a ejercitarse en el tiro al arco; finalmente, me pidió permiso para ir en busca de su hermano que debía encontrarse en Bahía Inútil. Después de quince días, me llegó en un estado lamentable. Fue alimentado y cambia-do entero de pies a cabeza, en la esperanza de que los padecimientos sufridos lo hubieran vuelto sabio en el futuro. ¡Inútil expectativa! Dos semanas después, el retorno en él de los instintos salvajes lo hicieron huir nuevamente, llevándose incluso la llave de la habitación. Cuando vino Monseñor Fagnano la primavera pasada, lo hizo buscar y lo recondujo a Punta Arenas. Todas estas contradicciones y dificultades, sin embargo, no nos asustan, en la esperanza siempre de poder ganar algún alma más para vuestro Señor y asegurar así salvar la nuestra”, Beauvoir, BS, año XX., n.2, febrero 1896.

55. Las informaciones de Perich Slater sobre "Covadonga" no tienen fuente y, considerando que "la figura de la Chonga era muy popular" (1995:147), las atribuimos a su memoria. 
56. “...y muchos menos se prestan a traducir inmediatamente lo que sus compatriotas digan. El ona es extremadamente receloso y reservado y no conozco caso de alguno que haya comunicado algo sobre las costumbres, creencias, ritos, etc., de la raza, si algo de los últimos existe entre ellos" ( $S$, ff. 189vta-190). Desmintiéndose una vez más, Señoret publicaría ese mismo año (1896) "La Tierra del Fuego y sus naturales", uno de las primeros ensayos antropológicos sobre la isla.

57. Este personaje es mitificado por Perich Slater (1995:139 y sgtes.) al mezclar fechas e informaciones, algunas cotejables y otras no. De entre ellas, es efectivo que "la única acusación pública a Felipe fue de don José Menéndez", estanciero de Río Grande (y también accionista original de la SETF) que lo acusó de robo de ganado y del incendio de un puesto en la estancia, persiguiéndolo con ayuda de la policía (Payró 1898:438). "Felipe" o Ishtohn es descrito como rápido corredor y ovejero temporal en la estancia la familia Bridges (Bridges 1949:483), donde se refugió (el misionero Zenone bautizó a sus hijos). Ishtohn no murió en 1899 como sugiere (Perich Slater 1995:143), sino que escapó a las epidemias, pues reencontró a Lucas Bridges en 1932 (1949:520). Pero el dato más sorprendente, el propio secreto de Perich Slater, es que cuando murió "Felipe", "se le encontró una carta dirigida por Covadonga [...], escrita en Ona" y "traducida por Kalafate" (1995:144), carta que no trascribe ni refiere.

58. En su vocación de infancia, Borgatello pretendía que los “ejemplos de pobres jóvenes rudos y salvajes del desierto americano [...] sirvan de estímulo para que también vosotros correspondáis e imitéis sus virtudes" y "motivo de grande confusión sería si, en el último día, puestos frente a estos pobres salvajes de la Tierra del Fuego, resultaseis inferiores a ellos, a pesar de las gracias que con tanta bondad y abundancia Dios os ha dado" (Borgatello 1924:10-11).

59. Sabemos que los salesianos utilizaron técnicas visuales para el adoctrinamiento cristiano, pero poco se sabe de su uso en las misiones. Por una aislada descripción del mismo Borgatello, descubrimos que una suerte de prehistoria cinematográfica con fines de éxtasis religioso ocurrió en Dawson en 1891: "En la tarde de esta primera fiesta, 5 de abril, he querido alegrarlo con un espectáculo novísimo. Había traído de Punta Arenas una linterna mágica con un organillo. ¡No se quería más! Reían, saltaban, bailaban, pataleaban; estaban todos emocionados. Su alegría era el colmo, su curiosidad era puesta a prueba. La mayoría de las imágenes eran temas sagrados. ¡Qué placer la sucesión repentina de nuevos personajes! ¡Cuántas exclamaciones, cuántas interrogaciones! A cada grupo yo hacía una breve explicación; pero al aparecer un Ser Humano no tuve tiempo de hablar; un grito unánime de júbilo estalló al instante: ¡Jesús, Jesús el Salvador! ¡Una escena conmovedora! Era un público acto de gracia, de reconocimiento, que este pobre pueblo ofrecía a ese Dios que hace poco habían aprendido a conocer. ¡Oh cómo lo habrá acogido Jesús! ¡Qué conmoción para su Corazón adorable! Toda la velada fue bella y agradó mucho a estos pobres salvajes", carta a don Rua, en Boletín Salesiano, n. 9, septiembre de 1891.

60. Gusinde afirmó algo similar respecto a su trabajo de salvación de la cultura: "De mala gana recuerdo el indecible esfuerzo y la paciencia de que tuve que armarme para sonsacar a esta gente indolente, desafecta a todo trabajo mental, la gran riqueza de elementos de su patrimonio cultural, difícil de obtener, y de la que hoy puedo gozar como fruto de mis investigaciones" (Gusinde 1990:162).

61. Memorias..., p. 34.

62. La primera expresión es de Holmberg (1906:70) cuando encontró las familias de los policíaspues-teros de José Menéndez, en la vecindad de Río Grande. En cuanto a los hijos, en un trabajo reciente (Bascopé 2010b) se contaron 17 familias de este tipo, registradas en los libros de la misión hasta 1920, cuyos hijos fueron bautizados por los salesianos en puestos y comisarías. De entre los puesteros, dos aparecen registrados en partidas de cacerías humanas y uno, Gregorio Prado, fue empleado de la SETF, participó en la captura de 1895 y declaró en el Sumario (ff. 253-254).

63. Como la precaria situación de los “jornaleros vagabundos" (Gusinde 1990:159) o policíaspuesteros: "Hoy por hoy, las comisarías están expuestas a morirse de hambre, si llega un crecido 
número de indios a presentarse y quieran cumplir con su deber (hay que creer que los víveres para 30 personas no pueden alcanzar para 100) o tener que faltar a él despidiendo a los indios o lo que es lo mismo que sigan su vida de depredaciones", informe del comisario argentino Ramón Cortés al Ministerio del Interior, 7-06-1895, citado en Penazzo 1995:240-243). Faltos de caballos, de víveres e incluso de alojamiento, no alcanzaban a mantenerse con la sola ayuda estanciera. "Para desempeñar una comisión [persiguiendo cazadores] de diez días", agregó Cortés en 1895, "he necesitado dos meses andando de un lado a otro, mendigando a personas extrañas y en un país extranjero, tan pronto alojamiento como medios de movilidad". En esas condiciones no se podían mantener criados ("mi equipaje y el muchacho indio lo he tenido que abandonar" (p. 243). Una situación similar vivieron algunos salesianos que, cuando la muerte amenazó el futuro de las misiones, optaron por salir en busca de sobrevivientes, instalándose a orillas del lago Fagnano. Iniciaron así una vida aislada, "llena de privaciones y sacrificios", al punto que "los indios" estaban "mejor en la misión que nosotros aquí", carta de Javier Vigne a José Fagnano, 26-10-1911, citada en Belza 1977:228.

64. En una estancia de la SETF se contrató a "dos ovejeros escoceses, solteros, y se los instaló en el puesto [...] junto al mar y algo apartado de Cameron. Allí permanecieron por espacio de dos meses entrega-dos a su trabajo [...] ambos trabajadores llevaron una vida en común, pero jamás se dirigieron la palabra" (Fuentes Rabé 1923: t. II, p. 52).

65. "El lazo entre hombre y hombre, ya sea por relación de sangre o simple amistad, es mucho más vinculante que el de hombre y mujer, incluso cuando son marido y esposa" (Barclay 1904:74). 66. Ya en uno de los primeros enfrentamientos registra-dos, el de la expedición de Lista a fines de 1886, Segers narró que, al ser "sorprendidos por nuestra llegada", los hombres adultos "hacían huir a mujeres e hijos hasta ponerlos fuera de nuestro alcance", "La Espedizion à la Tierra del Fuego. Correspondencia de Dr. Seger, Bahía Tetis, Enero 1887", manuscrito inédito, ACS, caja A842 "Missioni Argentina. Patagonia meridionale". Confirmando esta simetría entre cazadores, Penazzo observó un "cambio conductual" reflejado "ya en 1896, cuando a fin del año en la crónica los misioneros perciben que los Onas les entregan mujeres y niños, en forma voluntaria para "consuelo" de los misioneros, que procuran evangelizar y para desgracia del grupo, que acepta la inevitable situación" (Penazzo 1995:264).

67. La fuga de mujeres hacia las misiones, como servidumbre o con los puesteros fue, según Bridges (1949:295), el principal motivo de violencia entre los cazadores fueguinos sobrevivientes durante la colonización. Esto alteró igualmente las relaciones de género. Así, mientras que el patriarcado fueguino permitía a los mejores cazadores poseer más de una mujer, en el nuevo contexto los "solteros, que en parte ya se acercan a los treinta, tratan de conseguir lo suyo manteniendo relaciones ilegales con mujeres casadas; éstas los admiten secretamente en ausencia del esposo, por compasión de su soledad" (Gusinde 1990:163).

68. "Incluso los niños siguen a las niñas o se descubren ante sus ojos, cuando no hay adultos presentes. Una vez observé cómo ocho muchachitos totalmente desnudos imitaban, en forma decididamente indecente, una danza Klóketen" (Gusinde 1990:162-163).

\section{ABSTRACTS}

The concept of "extinction"-or no survivors-was adopted early in the writing of the history of Tierra del Fuego. During the same period, when certain animal species-such as sea lions or whales- faced the risk of extinction due to fishing, and the guanaco or coruros by ranches, the 
"Indian" expanded as a threat to livestock and was therefore threatened with extinction. In late 1895, an expedient called Sumario por vejámenes inferidos a indíjenas de Tierra del Fuego was initiated due to the capture and deportation of 165 people. From the Summary, we will discuss the figure of extinction showing how colonization did not end Indian existence, but rather built it as an object, either of hunting, civilization, mission and later of anthropology. The text provides evidence of the abduction and forced adoption of fueguinos children as a mass practice due to the lack of servitude, that involved not only missionaries, but officials and businessmen, among other agents.

We argue that the presence of the Indian serving the domestic colonial space caused his original registration both as living prehistory and as history childhood. Finally, we will see how the stronghold of purity - of "culture"-inherited by anthropology from the Mission, was not a cunning rhetoric but an actual practice of infantilization. Threatened with death, the Mission prepared the text of extinction, excluding native life that served domestically as an outsider, that being impure, was also missed by the ethnological text.

La figura de la "extinción" - o ausencia de sobrevivientes- se adoptó temprano en la escritura de la historia fueguina. Durante un mismo período, en que arriesgaron extinguirse ciertas especies animales -como el lobo marino o la ballena por la pesca, el coruro o el guanaco por las estancias -, se expandió el "Indio" como una amenaza para el ganado y, por tanto, amenazado de extinción. A fines de 1895, se inició un Sumario por vejámenes inferidos a indíjenas de Tierra del Fuego, por la captura y deportación de 165 personas. A partir del Sumario, discutiremos la figura de la extinción mostrando cómo la colonización no acabó al Indio, sino más bien lo originó como objeto - de caza, de civilización, de misión y más tarde de antropología. Aportaremos pruebas sobre el secuestro y adopción forzada de niños fueguinos como una práctica masiva, motivada por la falta de servidumbre, que involucró no sólo a misioneros, sino a funcionarios y empresarios, entre otros agentes. Sostendremos que la presencia del Indio sirviendo el espacio doméstico colonial fundó su inscripción primitiva a la vez como prehistoria con-viviente y como infancia de la historia. En fin, veremos cómo el reducto de pureza - de "cultura"- heredado por la Misión a la Antropología, no fue una astucia retórica sino una práctica concreta de infantilización. Amenazada de muerte, la Misión preparó el texto de la extinción, excluyendo la vida nativa que servía - domésticamente- fuera de ella y que, por impura, también olvidó el texto etnológico.

\section{INDEX}

Keywords: extinction, Salesians, Tierra del Fuego, Indian, colonization

Palabras claves: extinción, salesianos, Indio, colonización

\section{AUTHOR}

\section{JOAQUÍN BASCOPÉ JULIO}

Doctorando en Sociología, École des Hautes Études en Sciences Sociales. Miembro del Laboratorio de Desclasificación Comparada.

Correo electrónico: joaquinbascope@gmail.com 